Copyright (C) 2020 University of Bucharest Printed in Romania. All rights reserved

ISSN print: $1224-5984$

ISSN online: $2248-3942$
Rom Biotechnol Lett. 2020; 25(2): 1440-1447

doi: $10.25083 / \mathrm{rbl} / 25.2 / 1440.1447$

Received for publication, March, 2, 2018

Accepted, May, 29, 2018

Original paper

\title{
In vitro susceptibility of prototheca unicellular algae to resorcin and rivanol
}

\author{
SORIN RĂPUNTEAN ${ }^{1 *}$, FLORE CHIRILĂ ${ }^{1}$, GHEORGHE RĂPUNTEAN ${ }^{1}$
}

${ }^{1}$ University of Agricultural Sciences and Veterinary Medicine Cluj-Napoca, Faculty of Veterinary Medicine, 3-5 Mănăștur Street, 400372, Romania

\begin{abstract}
Resorcin and Rivanol are known as substances with antiseptic properties (bactericidal and/or fungicidal), widely used in the treatment of various skin conditions. Their effect on Prototheca is not known, which justifies research on this topic.

For testing purposes, we have used Resorcin (5\% aqueous solution) and Rivanol (solution for external use, 1\%). We have tested 22 strains of P. zopfii, isolated from cows' milk with mastitis and from manure collecting ditches. The strains were identified based on morphological, cultural and biochemical properties. A reference strain of $P$. wickerhamii 16529 ATCC was also tested. Verification of the anti-algal effect was determined by the agar diffusion test (for 22 strains), using different amounts of each product (10 $\mu 1,20 \mu 1$, and $40 \mu \mathrm{l}$ ), distributed in wells of $6 \mathrm{~mm}$ diameter. In 5 strains of $P$. zopfii and the $P$. wickerhamii strain, the inhibitory effect was also determined through the liquid dilution method, but also considering contact time. Prototheca strains were grown on broth and glucose agar, but for the assay, suspensions were applied to density 1 according to McFarland standards.

Both tested products had an anti-algae effect, algicidal in the case of Resorcin and algistatic in the case of Rivanol.
\end{abstract}

Keywords Prototheca, resorcin, rivanol.

To cite this article: RĂPUNTEAN S, CHIRILĂ F, RĂPUNTEAN GHE. In vitro susceptibility of prototheca unicellular algae to resorcin and rivanol. Rom Biotechnol Lett. 2020; 25(2): 1440-1447. DOI: $10.25083 / \mathrm{rbl} / 25.2 / 1440.1447$

*Corresponding author: SORIN RĂPUNTEAN, University of Agricultural Sciences and Veterinary Medicine Cluj-Napoca, Faculty of Veterinary Medicine, 3-5 Mănăștur Street, 400372, Romania E-mail: sorin.rapuntean@gmail.com 


\section{Introduction}

Unicellular algae of the genus Prototheca are more frequently reported in the production of localized or systemic diseases in humans (W-S. LEE et al [21]); (Z.C. KAMINSKI et al [16]); (LASS-FLÖRL et al [20]) and in various species of domestic animals. Of these, the more commonly reported are cows' mastitis (sometimes endemic outbreaks) (E.O. COSTA et al [7]); (E.O. COSTA et al [8]); (H.E. JENSEN et al [15]) and sporadic diseases in dogs (N. BUYUKMIHCI et al [3]); (J.R. Jr. COOK et al [6]); (J.R. BLOGG et J.E. SYKES [2]); (C. SALVADORI et al [31]) and cats (W. KAPLAN et al [17]); (P.J. COLE et al [5]); (J.E. DILLBERGER et al [10]). Diseases are also reported in some wild animals: bat (F. METTLER [24]), snake (C.G. CRISPENS et al [9]) and fish (J.C. GENTLES et al [12]); (G. LOUPAL et al [22]); (T. JAGIELSKI et al [14]). In animals, illnesses occur in weakened organisms, with different forms of immunodeficiency, chronic diseases or antibiotic abuse. In humans, illnesses are more commonly reported in HIV-infected individuals (Z.C. KAMINSKI et al [16]); (R.H. LAENG et al [19]) or in the presence of other chronic medical conditions (K. TAKAKI et al [33]); (A.J. MOHABEER et al [26]). Prototheca, once entered the body, produce local granulomatous lesions, but can spread lymphatically by producing a systemic, or even generalized infection, followed by fatal outcome. Such evolutionary forms have been described in cows (H. TANIYAMA et al [34]), dogs (D.E. TYLER et al [35]); (S.D. GAUNT et al [11]); (G.D. IMES et al [13]); (N. LIZA SOUZA et al [32]) and in humans, after immunosuppressive therapy (I.D. WOLFE et al [37]) or in immunocompromised hosts (F.A. WIRTH et al [36]).

Treatment of Prototheca infections often encounters difficulties or fails, especially in the disseminated form, and it is found that even if some improvements are made, they are temporary, with infections recurring, and it is justified to state that no effective treatment is known. Therapy does not provide results due to granulomatous lesions in different tissues/organs, and their architecture and normal functioning are seriously altered, requiring the slaughter or euthanasia of diseased animals (N. BUYUKMIHCI et al [3]); (P.J. COLE et al [5]); (H. KRUKOWSKI et al [18]); (N. BUYUKMIHCI et al [3]); (P.J. COLE et al [5]).

Resorcin is a meta-isomer of benzenediol. The recommended name is Benzene-1,3-diol (by the International Union of Pure and Applied Chemistry in its Recommendations for the Nomenclature of Organic Chemistry) [43]. It has astringent, antiseptic, disinfectant and keratolytic action. It is included in the composition of conditioned mixtures in the form of solutions (2-5\%), eye drops (1-2\%), ointments (10\%) as well as various shampoos [43]. They are recommended for treating medical conditions such as psoriasis, chronic eczema, skin mycoses, acne, wound antisepsis and others [40]. Resorcin is not absorbed through the skin and produces no side effects. It may be stored in tightly closed containers and away from light [42].
Rivanol is part of the group of organic dyes with antiseptic properties. The commercial product that we have used contains $1 \mathrm{~g}$ of ethacridine lactate $/ 1000 \mathrm{ml}$ of distilled water. It is used as such, undiluted [38]. In animals, it is recommended for dogs and cats, for the asepsis of wounds, urogenital, oral or conjunctival mucosa, and infected eczema [38]. It has bactericidal action, especially on Grampositive bacteria [39]; [41]. It does not influence the phagocytic leukocyte activity [39]. Long-term use may delay the forming of scar tissue on the wounds [38]. It is non-irritating and non-toxic.

The present study aims to test the in vitro efficacy of Resorcin and Rivanol for Prototheca zopfii strains isolated from cows' milk and from manure collection ditches from cattle shelters. The strains have been isolated through the course of many years and are being kept in the Microorganism Collection of the Department of Microbiology of the Faculty of Veterinary Medicine from Cluj-Napoca. A collection strain of Prototheca wickerhamii: ATCC 16529 was also examined.

\section{Materials and Methods}

The $P$. zopfii strains have been identified based on the following features: morphological (ovoid or kidney shape aspect, 20-30 $\mu \mathrm{m}$ in size, highlighting endospores presence, size and layout constituting an important identification criterion); cultural (cultivation on liquid and solid nutritive media with glucose, development at $37^{\circ} \mathrm{C}$, the formation of characteristic colonies: $3-4 \mathrm{~mm} \varnothing$, matte white color, slightly lobed edges and blackberry or cauliflower-like appearance); biochemical (glucose, glycerol and fructose fermentation, variable to other sugars, catalase and oxidasepositive reaction, negative to indole and $\mathrm{H}_{2} \mathrm{~S}$ ). In order to test their sensitivity, we used Resorcin (5\% aqueous solution, pharmaceutical preparation) and Rivanol (ethacridine lactate) (solution for external use 1\%o VITALIA SRL Ploieşti).

Determination of inhibitory effect by agar diffusion test. The antibiogram technique has been used, with the necessary adaptations for testing the products in solution form. For testing, the strains were cultured in glucose broth and incubated at $37^{\circ} \mathrm{C}$ for 48 hours. From these cultures, inoculations ( $1 \mathrm{ml}$ culture at density 1 on McFarland scale) were performed in $90 \mathrm{~mm}$ diameter Petri dishes (divided into two halves) in which the agar (Nutrient agar from UK company LAB Neogen) was previously poured and glucose (10\% solution) was added. The agar layer in the dish was $3 \mathrm{~mm}$ thick. Once the inoculum was dispersed (by repeated tilting and rotation of the dishes), excess liquid was removed, then the dishes were placed in the incubator, with the lid ajar, for 30 minutes. Following this step, $6 \mathrm{~mm}$ diameter wells were cut into the agar gel, grouped by 3 in each half, in which the following amounts of the tested products were dispensed: $10 \mu 1,20 \mu 1,40 \mu 1 /$ well. The dishes were then incubated at $37^{\circ} \mathrm{C}$ and examined within 24 and 48 hours, assessing the presence or absence of inhibition zones. Where inhibition zones presented, their diameter 
was measured (in mm). To check if the inhibitory effect was of algicidal type, inoculations were made in the glucose broth, using surfaces from the inhibition areas (at $40 \mu \mathrm{l} /$ well).

Determination of the inhibitory effect by dilution. For this purpose, two series of tubes were prepared in which $4.5 \mathrm{ml}$ of glucose broth were placed: 5 tubes for Resorcin and 5 tubes for Rivanol; 3 control tubes were added: 1 for Resorcin, 1 for Rivanol and 1 for culture verification. In the first tube of each series, $0.5 \mathrm{ml}$ of each product were added, from which, after homogenization, $0.5 \mathrm{ml}$ were passed successively into the following tubes, eliminating $0.5 \mathrm{ml}$ from tube no. 5. Thus, a dilution of the tested products was obtained at ax 10 rate $\left(10^{-1}, 10^{-2}, 10^{-3}, 10^{-4}, 10^{-5}\right)$. Subsequently, each tube was inoculated with a fixed amount of $10 \mu \mathrm{l}$ of the liquid culture of some Prototheca zopfii strains and the Prototheca wickerhamii strain. In control tubes 1 and $2,0.5 \mathrm{ml}$ of Resorcin, respectively Rivanol were introduced (for sterility testing), and $0.5 \mathrm{ml}$ of the culture was introduced into tube 3 (to check the development of the culture). All tubes were incubated at $37^{\circ} \mathrm{C}$ for 24 hours. Afterwards, glucose agar inoculations were performed from each tube with the dilutions using a single dish for each strain tested, the dish being divided into 5 sections of appropriate triangular shape for each dilution. This was done to check the inhibitory effect. For the control tubes, another Petri dish was used, divided into three triangular sectors. The dishes were incubated at $37^{\circ} \mathrm{C}$ and interpreted at 24 and 48 hours (but under observation for another 5 days).

Determining the inhibitory effect at different contact times. The strains tested were the ones used in the dilution method. We introduced $0.9 \mathrm{ml}$ of Resorcin and Rivanol respectively into 2 tubes $(10 / 110 \mathrm{~mm})$ and $0.1 \mathrm{ml}$ of broth culture of the tested strains (density 1 on the McFarland scale) was added to each tube. Contact times were 5', $10^{\prime}, 15^{\prime}, 30^{\prime}$ and $60^{\prime}$. After the expiration of each contact time, glucose agar inoculations were performed, following the division of the Petri dishes into 5 triangular sectors. Dishes were incubated at $37^{\circ} \mathrm{C}$. Interpretation was done at 24 and 48 hours, but the dishes were kept under observation for another 5 days.

\section{Results and Discussions}

A. Using different amounts of Resorcin and Rivanol distributed in wells $(10,20$ and $40 \mu \mathrm{l} /$ well $)$

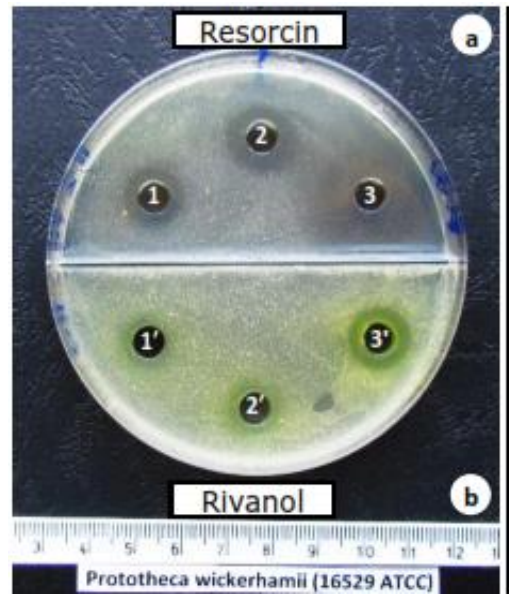

Figure 1. Inhibition zones at different amounts of tested products

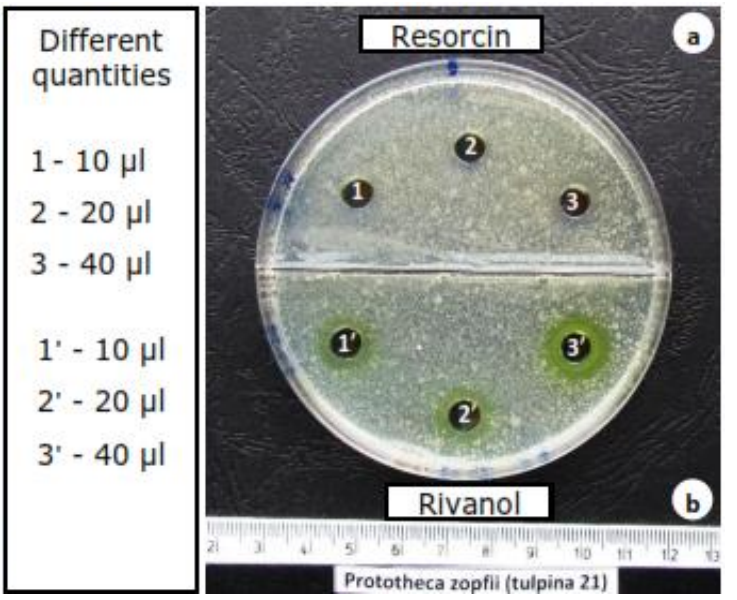

Figure 2. Inhibition zones at different amounts of tested products (strain 21)
When analyzing the areas of inhibition of $P$. wickerhamii, it is observed that it is susceptibile to Resorcin, with inhibition zones between 14 and $24 \mathrm{~mm}$, higher at $40 \mu \mathrm{l} /$ well (Figure 1a); sensitivity was also observed in Rivanol, with smaller inhibition areas, ranging from 10 to $18 \mathrm{~mm}$ (Figure $1 \mathrm{~b}$ ). In the case of $P$. zopfii strains, it was found that they were less susceptible to Resorcin, with absent or poorly expressed inhibition zones, sized 10-12 mm, and only at $40 \mu \mathrm{l} /$ well (Figure 2a); for Rivanol, inhibition zones were found in all amounts deposited in wells with sizes between 10-14 mm, larger and better expressed at $40 \mu \mathrm{l} /$ well (Figure $2 \mathrm{~b}$ ).

Inoculations from the inhibition areas (at $40 \mu \mathrm{l} /$ well) allowed us to conclude that the nutritional broth remained sterile in the case of $P$. wickerhamii (algicidal effect) and the culture was developed only in the case of $P$. zopfii (algistatic effect). The same aspect was also found in the nutrient agar. 
B. Different dilutions (rate $\mathrm{x} 10$ ) of the two products: $10^{-1}, 10^{-2}, 10^{-3}, 10^{-4}, 10^{-5}$

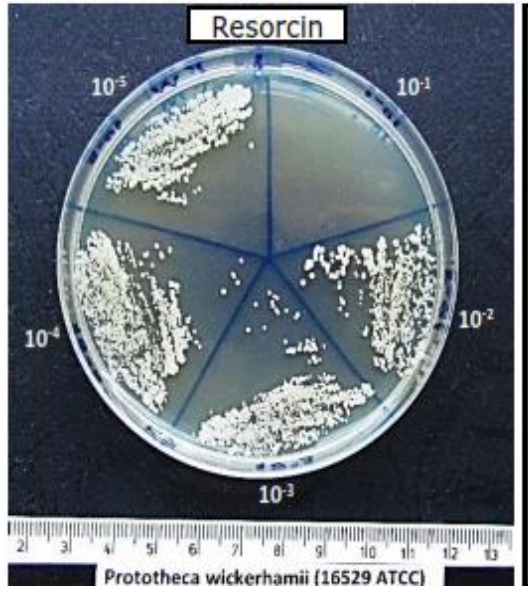

Figure 3. Inhibition at dilution of $10^{-1}$

\begin{tabular}{|c|}
$\begin{array}{c}\text { Dilutions } \\
\text { of the } \\
\text { products } \\
\text { used }\end{array}$ \\
$10^{-1}$ \\
$10^{-2}$ \\
$10^{-3}$ \\
$10^{-4}$ \\
$10^{-5}$
\end{tabular}

Figure 4. Lack of inhibition of all dilutions
Using these dilutions, there were differences in the inhibitory capacity of the two tested substances, compared to the examined Prototheca species.

In the case of $P$. wickerhamii, it was found that Resorcin inhibits its development at $10^{-1}$ dilution, but not at higher dilutions $\left(10^{-2}\right.$ to $\left.10^{-5}\right)$ (Figure 3$)$. Rivanol did not induce inhibition at any of the dilutions (Figure 4), which is explained by the fact that the product is manufactured at a concentration of $1 \%$ and recommended to be used as such.

In the case of $P$. zopfii strains (5 strains examined under the same conditions), it was found that no inhibition was observed in either of the dilutions performed for both Resorcin and Rivanol (Figures 5 and 6).

For both products, in dilutions without inhibition, colony development in the triangular areas corresponding to the respective dilutions can be observed for both $P$. wickerhamii and $P$. zopfii dishes. However, a lower density of colonies can be observed at the $10^{-1}$ dilution.

This observation concludes that in order to obtain an inhibitory effect, the two products should be used as such and not diluted. We mention that they are photosensitive products and must be stored under conditions that avoid degradation (dark-colored bottles, in dark areas and at an appropriate temperature).

The control tubes in which Resorcin (tube 1) or Rivanol (tube 2) were inserted remained clear, demonstrating that the two tested products were sterile, also confirmed by inoculation in Petri dishes, which showed no colonies in the corresponding areas.

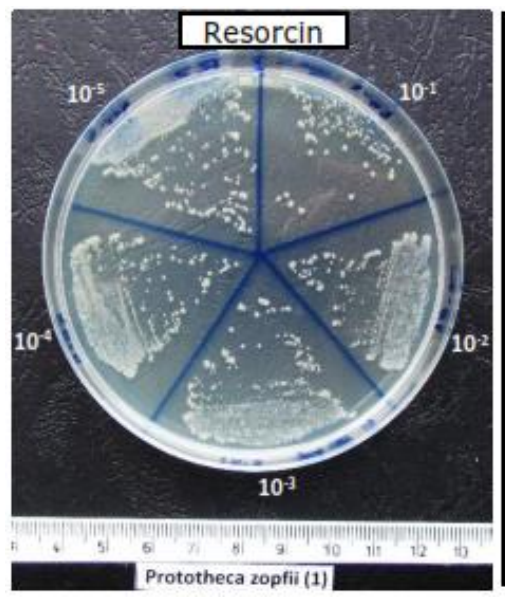

Figure 5. Lack of inhibition at all dilutions

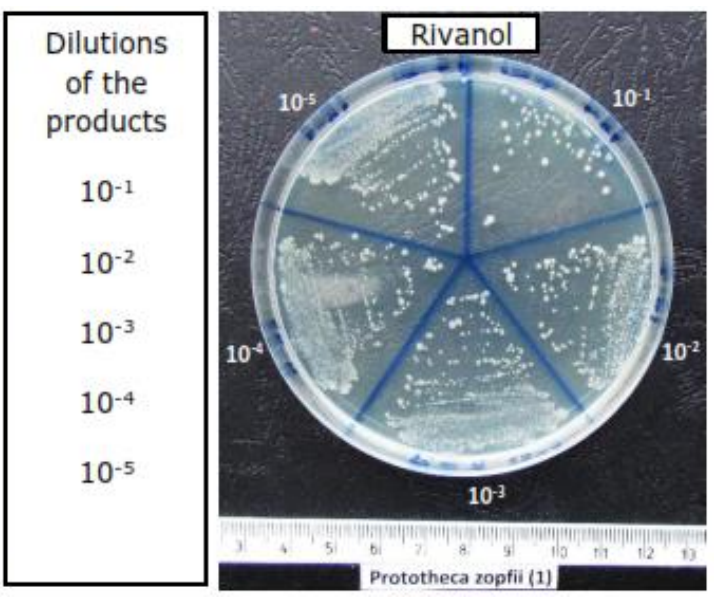

Figure 6. Lack of inhibition at all dilutions
The tube for culture development verification (tube 3) showed turbidity and microscopic control (wet smear in Lugol solution) revealed microorganisms with typical morphology for $P$. wickerhamii and $P$. zopfii respectively.
Inoculations carried out in glucose agar on Petri dishes, yielded colonies typical of each Prototheca species. Aspects of the results obtained in the control dishes for the 3 control tubes are shown in Figures 7 and 8. 


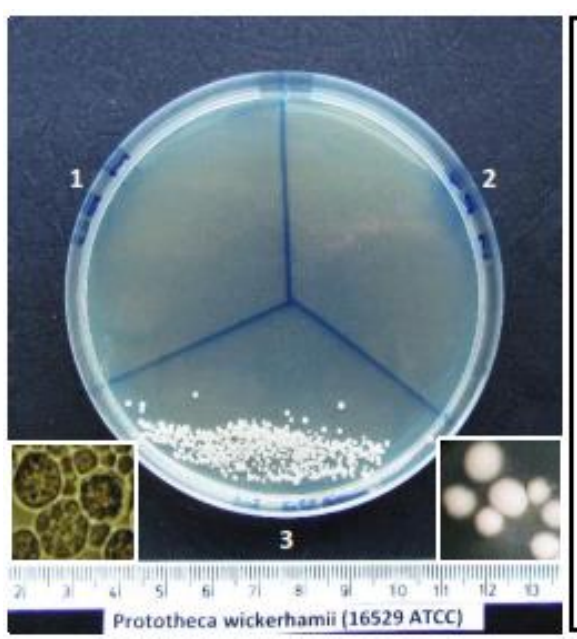

Figure 7. Resorcin (1), Rivanol (2) $P$. wickerhamii colonies (3)
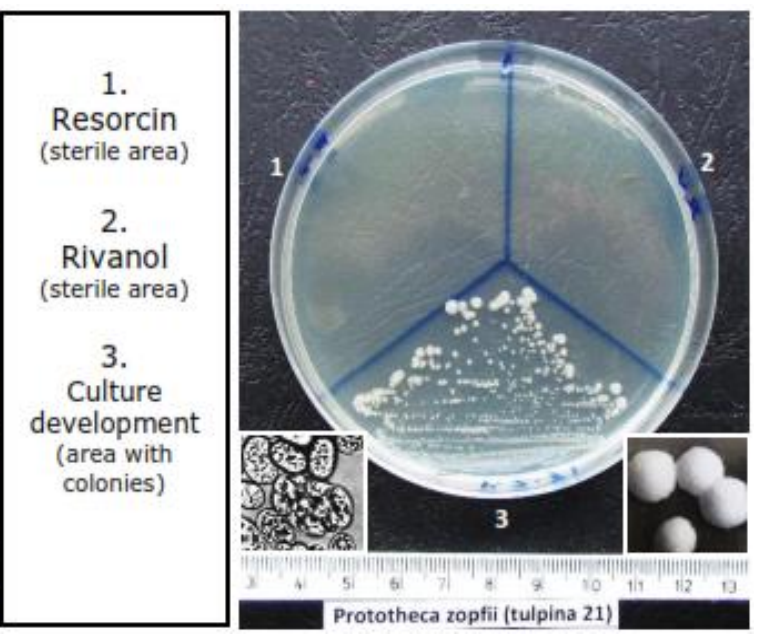

Figure 8. Resorcin (1), Rivanol (2) P. zopfii colonies (3) (strain 21)

C. Aspects of inhibition (at different contact times:

\section{$5,10,15,30$ and 60 minutes)}

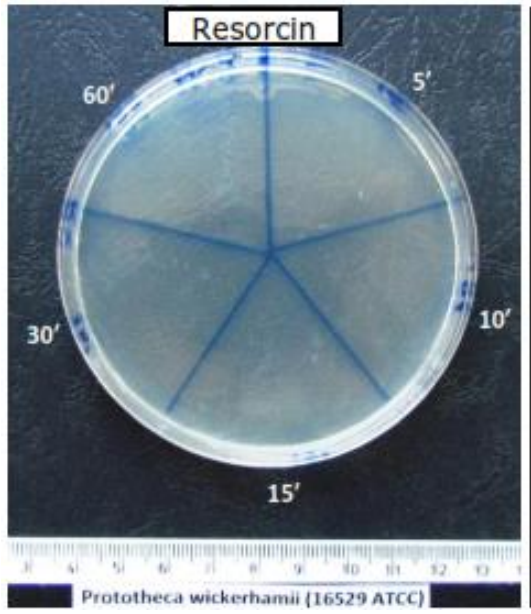

Figure 9. Inhibition at all contact times

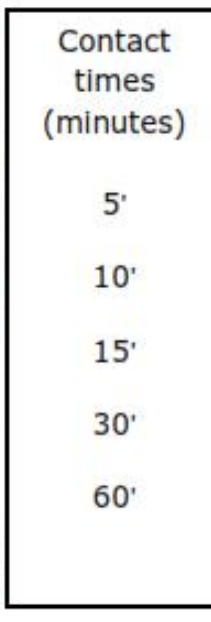

Figure 10. Inhibition after 30' contact

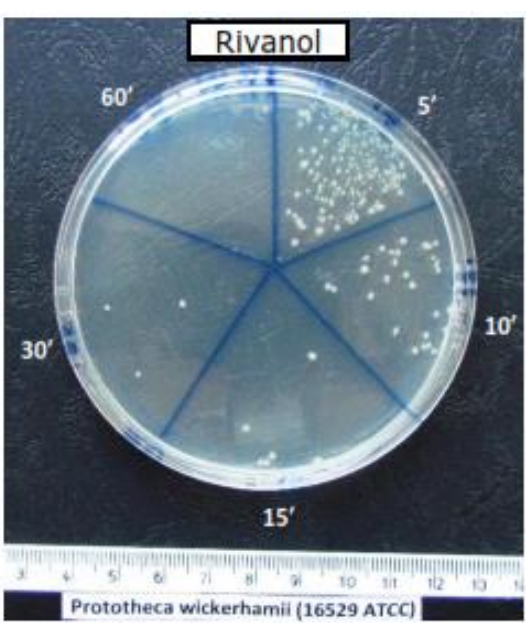

The $P$. wickerhamii strain was found to be very susceptible to Resorcin, with inhibition in the first 5 minutes of contact (Figure 9), in contrast with reduced sensitivity to Rivanol, with total inhibition after 30 minutes of contact (Figure 10). In the pictures below we can observe the lack of colonies in the Resorcin dish (at all contact times) and their presence in the Rivanol dish, denser at 5, 10 minutes and rarer

The $P$. zopfii strains were inhibited by Resorcin when contact exceeds 10 minutes (Figure 11), and by Rivanol when it exceeds 30 minutes (Figure 12). The images show the development of colonies in the Resorcin dish at 5 and 10 minutes, and in the Rivanol dish at 5 and 10 minutes, and rare colonies at 15 and 30 minutes of contact. 


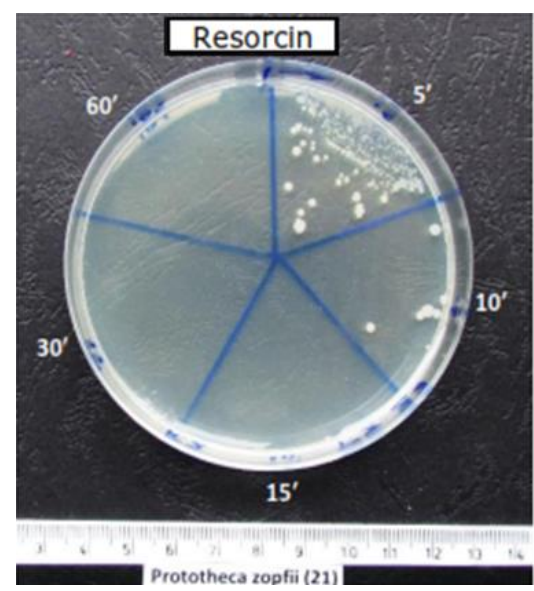

Figure 11. Inhibition after 10' contact (P. zopfii strain 21)

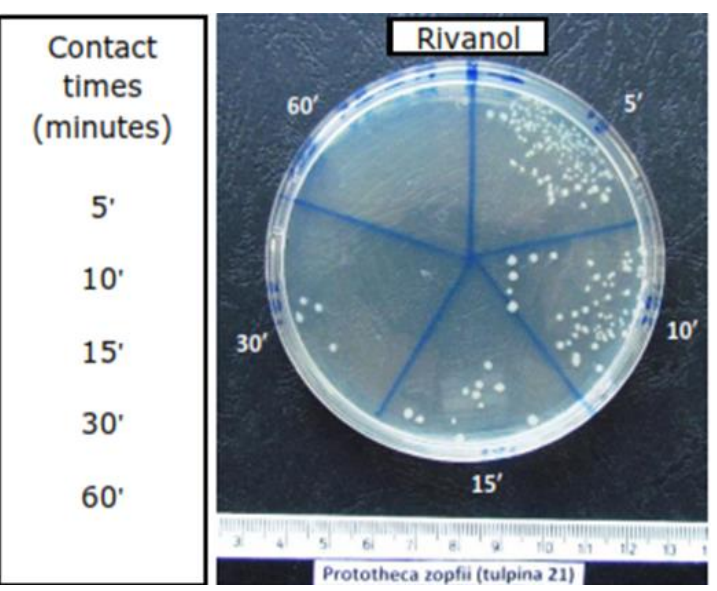

Figure 12. Inhibition after 30' contact (P. zopfii strain 21)
Resorcin is derived from phenol, so the mechanism of action is integrated into the effects induced by it [42]; [43]. It is mentioned that in small concentrations $(0.02-$ $0.1 \%$ ) it acts as bacteriostatic, and at $5 \%$ it is bactericidal by precipitation of proteins. Its antiseptic action is due to the $\mathrm{OH}$ group that reacts with the basic groups of proteins, producing colloidal changes [43]. Phenol destroys vegetative forms of microorganisms in 30-90 minutes, Grampositive germs showing increased sensitivity compared to Gram-negative ones [40]; [43]. The investigations show that Resorcin has an inhibitory effect on algae of the genus Prototheca, which is more intense for $P$. wickerhamii strains (more commonly involved in the production of human diseases) and weaker on $P$. zopfii strains (more frequently involved in the production of animal diseases). The fact that there are some morphological differences between the two species that influence the behavior to some substances is also underlined by the different sensitivity to clotrimazole, to which $P$. wickerhamii strains show sensitivity, whilst $P$. zopfii show resistance (M.J. CASAL et al [4]).

Rivanol (ethacridine lactate) is known for its antiseptic action (bactericide) and it is used to render wounds, as well as urogenital, oral or conjunctival mucous membranes aseptic $[38,41]$. As for the action mechanism, it is shown that the bactericidal effect is determined by the combination with the nucleic acids of the microbial cells, by inhibiting the synthesis of the ribosomal proteins [38]; [44]. It has a strong antibacterial effect on the surface of the skin, it is non-irritating and non-toxic [39]; [44]. Bactericidal action is more intense on Gram-positive bacteria, especially streptococci and staphylococci [39]. Our research demonstrates that Rivanol exhibits antialgal activity, with an algistatic inhibitory effect, of similar intensity in both $P$. wickerhamii and $P$. zopfii.
Treatment of infections with Prototheca species remains a difficult problem. Different studies have proven the efficacy of certain antibiotics (lincocin forte, neomycin, kanamycin, colistin, gentamycin), antifungals (mycostatin, ketoconazole, econazole, itraconazole, batrafen, amphotericin B (G. RĂPUNTEAN et al [27]), iodine-based products (iodine tincture, betadine, Videne Antiseptic Solution) (S. RĂPUNTEAN et al [28]), copper hydroxyquinoline-based preparations deposited on hydroxyapatite (S. RĂPUNTEAN et al [30]) and guanidine (A.C. ALVES et al [1]). However, in vivo results are often unsatisfactory, especially in systemic forms where serious destructive lesions occur and the tissues suffer serious irreversible alterations.

Given the broad spectrum of affected hosts and increasing reports of cases in both animals and humans, it is justified to carry out research to verify the anti-algal efficacy of different substances in order to increase their therapeutic chances. Consideration should be given to the phenomenon of increased risk for public health, due to milk dissemination with high values, which can go up to $10^{3} / \mathrm{ml}$ (J.S. MCDONALD et al [23]). In this context, it is shown that in some cattle farms, predominantly in the last 10 years, mastitis with Prototheca became an issue of emerging pathology, leading to important economic losses (D. MILANOV et al [25]); (A.C. ALVES et al [1]). For this reason, some countries have initiated epidemic surveillance programs.

Based on the research results, it can be stated that both Resorcin and Rivanol have an inhibitory effect on both Prototheca species, with some differences regarding the size of inhibition zones, product dilution or contact time. Consequently, it can be stated that the two tested products show anti-algal action, beside the known bactericidal and fungicidal properties. This also results in practical appli-cation in the treatment of cutaneous protothecosis. 


\section{Conclusion}

Resorcin exhibits a stronger inhibitory effect on $P$. wickerhamii (14-24 $\mathrm{mm})$ and lower on $P$. zopfii (10-18 mm).

Rivanol has an inhibitory effect on both $P$. wickerhamii and $P$. zopfii, the inhibition areas being similar in size (10-14 mm).

The inhibitory effect against $P$. wickerhamii occurs in the first 5 minutes with Resorcin and after 30 minutes with Rivanol, and against $P$. zopfii after 10 minutes with Resorcin and 30 minutes with Rivanol.

The inhibitory effect is algicidal to $P$. wickerhamii and algistatic to $P$. zopfii.

\section{References}

1. A.C. AlveS, E. CAPRA, S. MORANDI, P. CREMONESI, J.F.C. PANTOJA, H. LANGONI, A.P.C. DE VARGAS, M.M. DA COSTA, T. JAGIELSKI, C.A.D. BOLAÑOS, S.T. GUERRA, M.G. RIBEIRO, In vitro algicidal effect of guanidine on Prototheca zopfii genotype 2 strains isolated from clinical and subclinical bovine mastitis. Lett. Applic. Microbiol., 64(6): 419-423 (2017).

2. J.R. BLOGG, J.E. SYKES, Sudden blindness associated with protothecosis in a dog. Aust. Vet. J., 72(4): 147-149 (1995).

3. N. BUYUKMIHCI, L.F. RUBIN, A. DEPAOLI, Protothecosis with ocular involvement in a dog. J. Am. Vet. Med. Assoc., 167(2): 158-161 (1975).

4. M.J. CASAL, J. GUTIERREZ, Simple New Test for Rapid Differentiation of Prototheca wickerhamii from Prototheca zopfii. J. Clin. Microbiol., 18(4): 992-993 (1983).

5. P.J. COLE, J.F. ALLISON, Protothecosis in a cat. J. Am. Vet. Med. Assoc., 180: 78-79 (1982).

6. J.R. JR. COOK, D.E. TYLER, D.B. COULTER, F.W. CHANDLER, Disseminated protothecosis causing acute blindness and deafness in a dog. J. Am. Vet. Med. Assoc., 184(10): 1266-1272 (1984);

7. E.O. COSTA, A.R. RIBEIRO, P.A. MELVILLE, M.S. PRADA, A.C. CARCIOFI, E.T. WATANABE, Bovine mastitis due to algae of the genus Prototheca. Mycopathologia, 137(2): 85-88 (1996).

8. E.O. COSTA, P.A. MELVILLE, A.R. RIBEIRO, E.T. WATANABE, M.C.F.F. PAROLARI, Epidemiologic study of environmental sources in a Prototheca zopfii outbreak of bovine mastitis. Mycopathologia, 137(1): 33-36 (1997).

9. C.G. CRISPENS, K.R. MARION, Algal infection in a Corn snake (Elaphe gutata gutata). Lab. Anim. Sci., 25(6): 788-789 (1975).

10. J.E. DILLBERGER, B. HOMER, D. DAUBERT, N.H. ALTMAN, Protothecosis in two cats. J. Am. Vet. Med. Assoc., 192(11): 1557-1559 (1988).
11. S.D. GAUNT, R.K. MCGRATH, H.U. COX, Disseminated protothecosis in a dog. J. Am. Vet. Med. Assoc., 185: 906-907 (1984);

12. J.C. GENTLES, P.M. BOND, Protothecosis of Atlantic salmon. Sabourandia, 15(2): 133-139 (1977).

13. G.D. IMES, J.C. LLOYD, M.P. BRIGHTMAN, Generalized protothecosis in a dog. Onderstepoort J. Vet. Res., 44(1): 1-6 (1977).

14. T. JAGIELSKI, M. DYLAG, U. ROESLER, J. MURUGAIYAN, Isolation of infectious microalga Prototheca wickerhamii from a carp (Ciprins carpio) a first confirmed case report of protothecosis in a fish. J. Fish. Dis., DOI:10.1111/jfd.12614 (2017).

15. H.E. JENSEN, B. AALBAEK, B. BLOCH, A. HUDA, Bovine mammary protothecosis due to Prototheca zopfii. Med. Mycol., 36(2): 89-95 (1998).

16. Z.C. KAMINSKI, R. KAPILA, L.R. SHARERE, P. KLOSER, L. KAUFMAN, Meningitis due to Prototheca wickerhamii in a patient with AIDS. Clin. Infect. Dis., 15(4): 704-706 (1992).

17. W. KAPLAN, F.W. CHANDLER, E.A. HOLZINGER, R.E. PLUE, R.O. DICKINSON, Protothecosis in a cat: first recorded case. Sabourandia, 14(3): 281-286 (1976).

18. H. KRUKOWSKI, A. LISOWSKI, B. NOWAKOWICZDEBEK, L. WLAZLO, Susceptibility of Prototheca zopfii strains isolated from cows mastitis to chlorhexidine and iodine. Turk. J. Vet. Anim. Sci., 37: 106108 (2013).

19. R.H. LAENG, C. EGGER, T. SCHAFFER, B. BORISCH, E. PEDRINIS, Protothecosis in an HIV, positive patient. Amer. J. Surg. Pathol., 18(12): 12611264 (1994).

20. CORNELIA LASS-FLÖRL, ASTRID MAYR, Human Protothecosis. Clin. Microbiol. Rev., 20(2): 230-242 (2007).

21. W-S. LEE, M.D. LAGIOS, R. LEONARDS, Wound infections by $P$. wickerhamii, a saprophytic alga pathogenic for man. J. Clin. Microbiol., 2(1): 62-66 (1975).

22. G. LOUPAL, E.S. KUTTIN, O. KÖLBL, Prototheca as the cause of swim bladder inflammation in carp (Cyprinus carpio). Tierarztl. Umschau, 47(11): 850854 (1992).

23. J.S. MCDONALD, J.L. RICHARD, N.F. CHEVILLE, Natural and experimental bovine intramammary infection with Prototheca zopfii. Am. J. Vet. Res., 45(3): 592-595 (1984).

24. F. METTLER, Generalized Protothecosis on a fruit bat (Pteropus lylei). Vet. Pathol., 12(2): 118-124 (1975).

25. D. MILANOV, T. PETROVIĆ, V. POLAČEK, L. SUVAJDŽIČ, J. BOJKOVSKI, Mastitis associated with Prototheca zopfii - an emerging health and economic problem on dairy farms. J. Vet. Res., 60: 373-378 (2016). 
26. A.J. MOHABEER, P.J. KAPLAN, P.M. SOUTHERN, M. GANDER RITA, Algaemia due to P. wickerhamii in a patient with myasthenia gravis. J. Clin. Microbiol., 35(12): 3305-3307 (1997).

27. GH. RĂPUNTEAN, I. GROZA, S. RĂPUNTEAN, PĂDURARU SIMONA, The sensitiveness of some Prototheca spp., to some antibiotics, antimycotic of some environmental factors. Bulletin USAMV-ZMV, 52: 95-99 (1998).

28. S. RĂPUNTEAN, GH. RĂPUNTEAN, F. CHIRILĂ, N. FIT, G. NADĂȘ, The Effect of Iodine Products on Unicellular Algae from genus Prototheca. Bulletin USAMV, Veterinary Medicine, 72(2): 306-313 (2015).

29. S. RĂPUNTEAN, GH. RĂPUNTEAN, N. FIT,, COSMINA CUC, G. NADĂȘ, Morphological and cultural characterization of some strains of unicellular algae of genus Prototheca sampled from mastitic cow milk. Notulae Botanicae, 37(1): 31-40 (2009).

30. S. RĂPUNTEAN, A. POP, V. MICLĂUȘ, C. GARBO, F. CHIRILĂ, GH. RĂPUNTEAN, N. FIȚ, H. FARCĂU, M. TOMOAIA-COTIȘEL, In vitro Sensitivity Research Concerning Some Microorganisms at Hydroxyquinoline and Cupric Derivate Deposited onto Hydroxyapatite. Bulletin USAMV, Veterinary Medicine, 73(2): 339350 (2016).

31. C. SALVADORI, G. GANDINI, A. BALLARINI, C. CANTILE, Protothecal granulomatous meningoencephalitis in a dog. J. Small Anim. Pract., 49: 531535 (2008).

32. N. LIZA SOUZA, ALESSANDRA LIMA-ESTRELA, L.T.E. MOREIRA, G.R. LORENA RIBEIRO, N.M. XAVIER, M.A.T. SILUA, A.E. COSTA, L.R. SANTOS, Systemic canine protothecosis. Case report. Braz. J. Vet. Pathol., 2(2): 102-106 (2009).
33. K. TAKAKI, K. OKADA, M. UMENO, M. TANAKA, T. TAKEDA, K. OHSAKI, Y. TAKAKI, Y. SAWAE, Chronic Prototheca meningitis. Scand. J. Infect. Dis., 28(3): 321-323 (1996).

34. H. TANIYAMA, F. OKOMOTO, T. KUROSAWA, H. FURUOKA, Y. KAJI, H. OKADA, K. MATSUKAWA, Disseminated Protothecosis caused by Prototheca zopfii in a cow. Vet. Pathol., 31(1): 123125 (1994).

35. D.E. TYLER, M.D. LORENZ, J.L. BLUE, J.F. MUNNELL, F.W. CHANDLER, Disseminated protothecosis with central nervous system involvement in a dog. J. Am. Vet. Med. Assoc., 176(10 Pt 1): 987-993 (1980).

36. F.A. WIRTH, J.A. PASSALACQUA, G. KAO, Disseminated cutaneous protothecosis in an immunocompromised host: a case report and literature review. Cutis, 63(3): 185-188 (1999).

37. I.D. WOLFE, H.G. SACKS, C.S. SAMORODIN, H.M. ROBINSON, Cutaneous protothecosis in a patient receiving immunosuppressive therapy. Arch. Dermatol., 112(6): 829-832 (1976).

38. *** Nomenclatorul Produselor Romvac, Rivanol, Ed. LVS Crepuscul, Ploiești, Prahova, p. 323 (2012).

39. *** Antiseptice și dezinfectante. www.scritub.com/ diverse/Antiseptice-si-dezinfectante9516924.php

40. *** Antiseptice și dezinfectante. www.ro.scrib.com/ doc/208683262/Antiseptice-Si-Dezinfectante

41. *** Rivanol. www.meduman.ro/produse-pentru-uzveterinar/100-rivanol-01-solutie-de-uz-veterinar

42. *** Resorcinolul. www.creaza.com/familie/medicina/ 43. *** Resorcina. htpps://ro.wikipedia.org

44. *** Rivanolul. www.sfatul.medicului.ro/arhiva-medicala/ rivanol-0-1-solutie- 